\title{
Suppression of Ceramide-induced Cell Death by Hepatitis C Virus Core Protein
}

\author{
Jung Su Kim, Jiyoon Ryu, Soon Bong Hwang , Soo Young Lee;, Soo Young Choi and Jinseu Park* \\ Department of Genetic Engineering, Division of Life Sciences, \\ Illsong Institute of Life Science, Hallym University, Chunchon 200-702, Korea \\ ${ }^{\dagger}$ Division of Molecular Life Science and Center for Cell Signaling, Ewha Womans University, Seoul 120-750, Korea
}

Received 18 June 2003, Accepted 8 July 2003

\begin{abstract}
The hepatitis $\mathrm{C}$ virus (HCV) core protein is believed to be one of viral proteins that are capable of preventing virusinfected cell death upon various stimuli. But, the effect of the HCV core protein on apoptosis that is induced by various stimuli is contradictory. We examined the possibility that the $\mathrm{HCV}$ core protein affects the ceramideinduced cell death in cells expressing the HCV core protein through the sphingomyelin pathway. Cell death that is induced by $\mathrm{C}_{2}$-ceramide and bacterial sphingomyelinase was analyzed in 293 cells that constitutively expressed the HCV core protein and compared with 293 cells that were stably transfected only with the expression vector. The HCV core protein inhibited the cell death that was induced by these reagents. The protective effects of the HCV core protein on ceramide-induced cell death were reflected by the reduced expression of $\mathrm{p}^{2} 1^{\mathrm{WAF} / \mathrm{Ci} 1 / \mathrm{Sid} 1}$ and the sustained expression of the Bcl-2 protein in the $\mathrm{HCV}$ core-expressing cells with respect to the vector-transfected cells. These results suggest that the $\mathrm{HCV}$ core protein in 293 cells plays a role in the modulation of the apoptotic response that is induced by ceramide. Also, the ability of the HCV core protein to suppress apoptosis might have important implications in understanding the pathogenesis of the HCV infection.
\end{abstract}

Keywords: Apoptosis, Ceramide, Core, HCV, Pathogenesis

\section{Introduction}

The Hepatitis $\mathrm{C}$ virus (HCV) has been identified worldwide as a causative agent of non-A, non-B hepatitis (Choo et al.,

*To whom correspondence should be addressed.

Tel: 82-33-248-2116; Fax: 82-33-256-3420

E-mail: jinpark@hallym.ac.kr
1989; Aach et al., 1991), which frequently leads to liver cirrhosis and hepatocellular carcinoma (Saito et al., 1990; DiBisceglie et al., 1994; Shimotohno, 1995). The details of the molecular processes that are involved in $\mathrm{HCV}$ pathogenesis are poorly understood. As an enveloped virus, $\mathrm{HCV}$ contains a single-stranded positive-sense RNA genome of approximately 9.5 kilobases (Kato et al., 1990; Inchauspe et al., 1991). The $\mathrm{HCV}$ proteins are initially produced as a precursor protein of approximately 3010 amino acids, which is cleaved into at least ten viral proteins (core, E1, E2, p7, NS2, NS3, NS4A, NS4B, NS5A, and NS5B) by both the cellular and viral proteases (Hijikata et al., 1991; Grakoui et al., 1993; Lin et al., 1994; Manabe et al., 1994; Park et al., 2000). The core and envelope proteins (E1, E2, and p7) are the structural proteins, while the remainders are nonstructural proteins.

The HCV core protein, as a major component of viral nucleocapsids consisting of 191 amino acids, is a multifunctional protein. Previous studies demonstrated that the $\mathrm{HCV}$ core protein is able to regulate many cellular events by interaction with cellular factors, transcriptional regulation of various cellular genes, and control of signal transduction pathways, which may have significant implications in HCV pathogenesis (reviewed in Ray and Ray, 2001). The HCV core protein activates the $c$-myc promoter, Rous sarcoma virus long terminal repeat, and simian virus 40 early promoter in human hepatocellular carcinoma cells (Ray et al., 1995). It also suppresses the promoters for $c$-fos, $\mathrm{p} 21^{\mathrm{WAF} / / \mathrm{ip} / \mathrm{Sid}}$, $\mathrm{p} 53$ tumor suppressor gene, and the human immunodeficiency virus (HIV) long terminal repeat (Ray et al., 1995; Ray et al., 1997; Ray et al., 1998). Furthermore, the HCV core protein exerts its oncogenic property in cooperation with ras oncogene in either primary rat embryo fibroblasts (Ray et al., 1996) or the Rat-1 cell line (Chang et al., 1998).

Apoptosis is one of the key elements in the host defense mechanism against the spread of infectious agents. Upon virus infection, the host cells produce various substances, such as TNF- $\alpha$, INF- $\gamma$ as a defense mechanism to eliminate virus- 
infected cells. To escape these cellular responses, many viruses evolved their gene products to suppress or delay apoptosis (Teodoro and Branton, 1997). Although the mechanisms by which HCV establishes viral persistence is unclear, it is believed that the HCV core protein is one of these gene products, since it can prevent virus-infected cell death upon various stimuli. At present, the effect of the HCV core protein on apoptosis that is induced by various stimuli is contradictory. The HCV core protein inhibited apoptosis that was mediated by cisplastin or the inappropriate expression of c-myc (Ray et al., 1996). The HCV core protein also inhibited the TNF- $\alpha$-induced apoptotic cell death of human breast carcinoma cells (MCF7) (Ray et al., 1998) and HepG2 cells (Marusawa et al., 1999). On the other hand, the HCV core protein sensitized the TNF- $\alpha$-induced apoptosis in murine BC10ME, HepG2, and HeLa cells (Zhu et al., 1998). In addition, a recent study showed that the HCV core protein induced apoptosis in Chinese hamster ovarian cells when accompanied by an increased expression of p53, p21 ${ }^{\text {Wafl }}$, and Bax (Honda et al., 2000). These discrepancies in the functional outcome of the HCV core protein in apoptosis may be due to different cell lines or different stimuli.

Ceramide is a sphingosine-based lipid signaling molecule that regulates various cellular responses to a variety of apoptotic stimuli. Diverse kinds of stresses (ultraviolet, irradiation, heat shock, and hypoxia) and biological factors (TNF- $\alpha$, IFN- $\gamma$, and Fas antibody) generate cellular ceramide that is able to induce apoptosis (Hannun, 1996). For example, TNF- $\alpha$ induces apoptosis and is known to stimulate the hydrolysis of sphingomyelin to form the lipid mediator, ceramide (Hannun, 1994). The functional outcome of ceramide to specific signaling cascades is both stimulus and cell-type specific. Therefore, ceramide action is determined within the context of other stimuli and by the subcellular topology of its production (Kolesnick and Kronke, 1998).

Our research goal was to determine whether the HCV core protein played a role in ceramide-mediated cell death. We determined that ceramide itself was able to induce apoptosis in 293 cells and the effect of the HCV core protein on apoptosis induced by ceramide. We report here that the core protein of human hepatitis C virus was able to protect 293 cells from apoptotic death that was induced by ceramide. The rescue from apoptosis by the $\mathrm{HCV}$ core was reflected by the reduced expression of $\mathrm{p} 21$ and the sustained expression of the $\mathrm{Bcl}-2$ protein in the $\mathrm{HCV}$ core-expressing cells.

\section{Materials and Methods}

Materials The chemicals were obtained from the Sigma Chemical Co. (St. Louis, USA). N-Acetyl-D-sphingosine $\left(\mathrm{C}_{2}{ }^{-}\right.$ ceramide) was prepared as a stock solution in ethanol and diluted to working concentrations with a culture medium. Bacterial sphingomyelinase from streptomyces $\mathrm{sp}$. was solubilized in a culture medium.
Cell culture and stable cell lines expressing the HCV core protein The human embryonic kidney (HEK) 293 cells were grown in Dulbecco's modified Eagle's medium that was supplemented with $10 \%$ fetal bovine serum (FBS). The pcDEFcore plasmid, which contained the full-length $\mathrm{HCV}$ core gene downstream of the human elongation factor $1 \alpha(\mathrm{EF})$ promoter, was constructed as previously described (Park et al., 2001). Briefly, the $\mathrm{HCV}$ core-encoding region (aa 1-191) of genotype $1 \mathrm{~b}$ was amplified by PCR using the Korean isolate of HCV (Cho et al., 1993). The HCV core gene was flanked with BamHI sites and inserted into the corresponding site of the pcDEF plasmid (Matsumoto et al., 1997). To obtain stable cells that expressed the HCV core protein, the pcDEF-core was transfected into the HEK 293 cells by the calcium phosphate method. The HEK 293 cell lines, containing either the pcDEF control or pcDEF-core plasmid, were selected in the presence of $0.5 \mathrm{mg} / \mathrm{ml}$ of $\mathrm{G} 418$ (Life Technologies Inc., Rockville, USA) by single-cell dilution (Park et al., 2001). The positive clones were identified by Western blot analysis using either a rabbit anti HCV core antibody (Lo et al., 1995) or a HCV patients' sera. Both cell types were maintained under $0.5 \mathrm{mg} / \mathrm{ml}$ of G418 (Kim et al., 2002).

Cell viability Cell viability was measured using trypan-blue exclusion methods (Kim et al., 2001). Stably-transfected cells were treated with $\mathrm{C}_{2}$-ceramide or bacterial sphingomyelinase for the indicated periods. The cells were harvested from wells and pelleted at $300 \times g$ for $10 \mathrm{~min}$, then resuspended in phosphate-buffered saline (PBS). A $0.4 \%$ solution of trypan-blue was added to the cells and the trypan-blue stained cells were counted with the aid of a hemacytometer.

Analysis of DNA fragmentation The cell lysate was prepared by lysing the cells in a solution containing $0.5 \%$ SDS, 100 mM EDTA, $10 \mathrm{mM}$ Tris- $\mathrm{HCl}$ (pH 8.0), $20 \mu \mathrm{g}$ of RNase A per ml, and $100 \mu \mathrm{g}$ of protease $\mathrm{K}$ per $\mathrm{ml}$, then incubated at $37^{\circ} \mathrm{C}$ for $1 \mathrm{~h}$ with gentle shaking. The DNA was then extracted twice with phenol/ chloroform and precipitated in ethanol. The DNA was electrophoresed on an $1.4 \%$ agarose gel. The gel was stained with ethidium bromide and photographed under UV light (Shim et al., 2002).

Cell extract preparation and Western blot analysis The cell extract was prepared by incubation with the lysis buffer $(125 \mathrm{mM}$ Tris- $\mathrm{HCl}, \mathrm{pH} 6.8,2 \% \mathrm{SDS}, 10 \%(\mathrm{v} / \mathrm{v})$ glycerol) at $4^{\circ} \mathrm{C}$ for $30 \mathrm{~min}$ (Lee et al., 2002). The protein concentration was determined by Bradford's method using bovine serum albumin as a standard (Bradford, 1976). Fifty $\mu \mathrm{g}$ of protein were electrophoresed in a $10 \%$ sodium dodecyl sulfate-polyacrylamide gel. The proteins were then electrotransferred to a nitrocellulose membrane, which was then blocked with $10 \%$ dry milk in PBS. The membrane was probed with primary antibodies, followed by incubation with horseradish peroxidase-conjugated secondary antibodies. The bound antibodies were then visualized by enhanced chemiluminescence according to the manufacturer's instructions (ECL; Amersham, Piscataway, USA). For detection of the HCV core protein, the membrane was probed with pooled sera from HCV-infected patients, followed by incubation with horseradish 


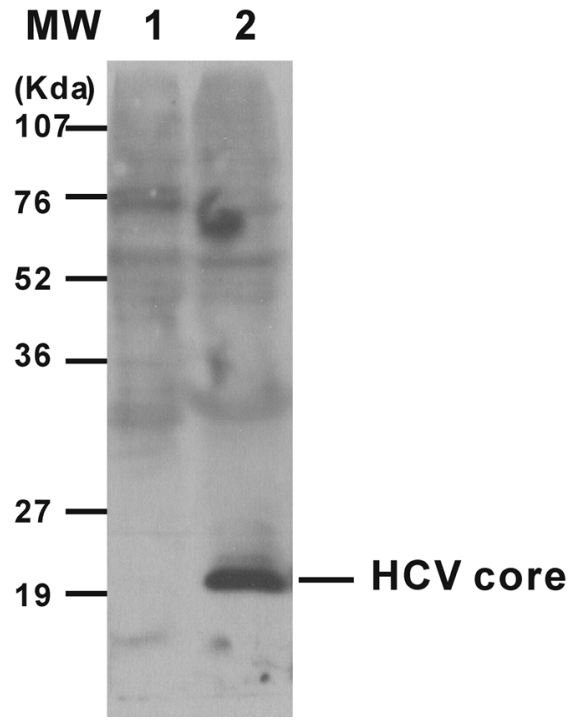

Fig. 1. Expression of the HCV core protein in the stablytransfected 293 cells. The cell lysates were prepared from stablytransfected 293 cells. The total proteins were electrophoresed in $10 \%$ sodium dodecyl sulfate gels. The expression of the HCV core proteins in the stably-transfected 293 cells was analyzed by Western blot using a mouse anti-HCV core antibody. Lane 1, cells transfected with control vector; lane 2, cells transfected with $\mathrm{HCV}$ core-expressing vector.

peroxidase-conjugated anti-human immunoglobulin G (Sigma Chemical Co., dilution $1: 10,000)$. For detection of the cellular proteins, primary antibodies against procaspase-3 (rabbit polyclonal antibody), PARP (mouse monoclonal antibody, Biomol, Plymouth Meeting, USA), Bcl-2 (mouse monoclonal antibody, Santa Cruz Biotechnology, Santa Cruz, USA), p53 (mouse monoclonal antibody, Santa Cruz Biotechnology), and p21 (mouse monoclonal antibody, Pharmingen, San Diego, USA) were used.

\section{Results}

Analysis of HCV core protein expressed in the HEK 293 cells Human embryonic kidney 293 cells were stably transfected with a plasmid vector containing the cDNA of the core gene from the Korean isolate of HCV under the control of the human elongation factor $1 \alpha$ promoter (Cho et al., 1993). The expression of the HCV core protein in the stablytransfected 293 cells was analyzed by Western blotting (Fig. 1). The proteins, separated by SDS-PAGE, were transferred to a nitrocellulose membrane by electroblotting, and followed by incubation with pooled sera from $\mathrm{HCV}$-infected patients. In the 293 cells, expressing the HCV core protein, the p21 core protein was evident, while no $\mathrm{HCV}$ specific protein was detected from the cells that were stably transfected with the control vector without the $\mathrm{HCV}$ core open-reading frame. Previously, we reported that the HCV core protein potentiates c-Jun N-terminal kinase activation through a signaling complex that involves TRADD and TRAF2 in the 293 cell
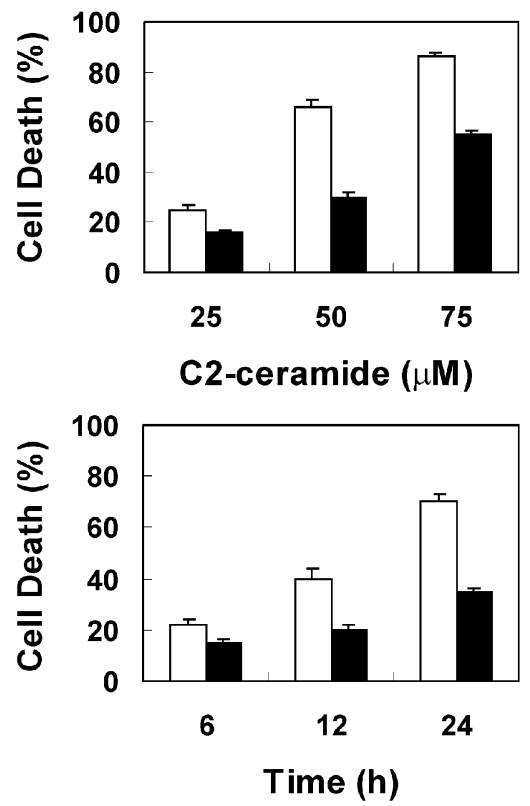

Fig. 2. Effect of HCV core protein expression on cell death induced by $\mathrm{C}_{2}$-ceramide. (A) The stably-transfected 293 cells were incubated with various concentrations of $\mathrm{C} 2$-ceramide for $24 \mathrm{~h}$. Cell death was measured by trypan blue exclusion methods. (B) The cells were incubated with $50 \mu \mathrm{M}$ C2-ceramide in a complete medium for various times, and cell death was measured as indicated in Materials and Methods. $\square$, cells transfected with control vector; $\boldsymbol{\square}$, cells transfected with HCV core-expressing vector. The results are presented as mean $\pm \mathrm{SD}$ in triplicate, and the bar represents the standard deviation.

lines expressing the HCV core that were used in this study (Park et al., 2001).

Effect of $\mathrm{C}_{2}$-ceramide and exogenous SMase on cell death of the 293 cell lines The effect of the HCV core protein on ceramide-induced cell death was analyzed in the 293 cells that constitutively expressed the HCV core protein. The cells were treated with $\mathrm{C}_{2}$-ceramide at increasing concentrations and the number of dead cells was determined after $24 \mathrm{~h}$ of treatment (Fig. 2A). Ceramide caused cell death of the control 293 cells in a dose-dependent manner. In the control cells that were treated with $50 \mu \mathrm{M} \mathrm{C} \mathrm{C}_{2}$-ceramide for various periods, timedependent cell death was observed (Fig. 2B). However, ceramide-mediated cell death was significantly reduced in the 293 cells that expressed the HCV core protein (Figs. 2A and B). The effects that were caused by ceramide were similarly determined by the administration of bacterial sphingomyelinase, which is known to generate the lipid second messenger ceramide (Figs. 3A and B). Cell death that was induced by the sphingomyelinase treatment was significantly inhibited in the cells that expressed the HCV core protein as compared to the control cells. These data demonstrate that the expression of the $\mathrm{HCV}$ core protein is able to rescue cells from cell death that is induced by ceramide. 

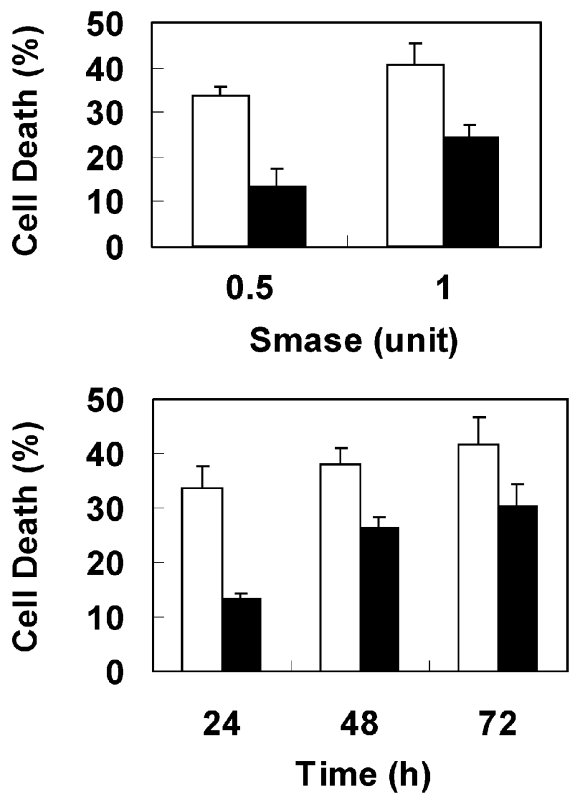

Fig. 3. Effect of HCV core protein expression on cell death induced by bacterial sphingomyelinase. (A) The cells were treated with bacterial sphingomyelinase at increasing concentrations, and the number of dead cells was determined after $24 \mathrm{~h}$ of treatment. (B) The effects caused by ceramide were similarly determined by the administration of $500 \mathrm{mU}$ bacterial sphingomyelinase for various times. $\square$, cells transfected with the control vector; $\mathbf{\square}$, cells transfected with the HCV core-expressing vector. Smase, bacterial sphingomyelinase. The results are presented as mean \pm SD in triplicate, and the bar represents the standard deviation.

Analysis of apoptotic cell death induced by ceramide in the 293 cell lines expressing the HCV core protein Apoptotic cell death was evaluated by the detection of DNA fragmentation. The DNA that was extracted from the $\mathrm{C}_{2}$-ceramide-treated cells was analyzed by agarose gel electrophoresis (Fig. 4A). As shown, exposure of the control cells to $50 \mu \mathrm{M} \mathrm{C}_{2}$-ceramide for $24 \mathrm{~h}$ resulted in a classical pattern of DNA fragmentation which is typical of apoptotic cell death. However, the DNA fragmentation that was induced by $\mathrm{C}_{2}$-ceramide was markedly reduced in the 293 cells that expressed the $\mathrm{HCV}$ core protein. A similar pattern of suppressive effect on DNA fragmentation that was induced by $500 \mathrm{mU}$ bacterial sphingomyelinase was obtained in the 293 cells that expressed the HCV core protein when compared to the control cells (data not shown). These results indicate that expression of the $\mathrm{HCV}$ core protein alters the cell death process that is induced by ceramide, suggesting a role of the $\mathrm{HCV}$ core protein in apoptosis that is induced by ceramide.

To further investigate the effect of the HCV core protein on the apoptotic signaling pathway, activation of the caspase-3 and Bcl-2 expression were analyzed in the control 293 cells and the 293 cells expressing the HCV core protein (Fig. 4B). Treatment of the control cells with $\mathrm{C}_{2}$-ceramide $(50 \mu \mathrm{M}$ and
(A)
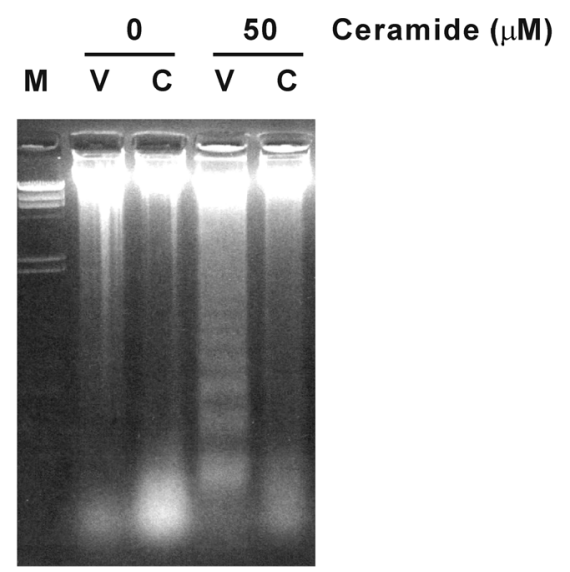

(B)

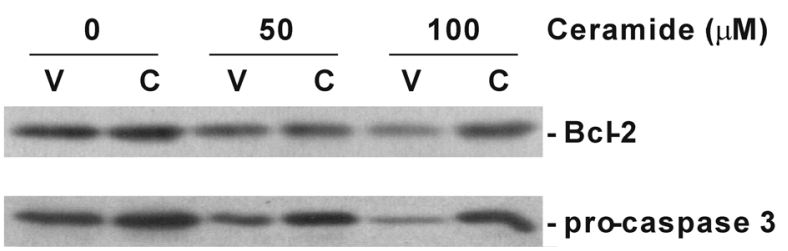

Fig. 4. Biochemical analysis of cell death induced by $\mathrm{C}_{2}$ ceramide in the stably-transfected 293 cells. (A) The stablytransfected 293 cells were incubated with $50 \mu \mathrm{M}$ ceramide for 24 h. Fragmentation of the DNA that was extracted from the cells was analyzed by agarose gel electrophoresis. (B) The stablytransfected 293 cells were incubated with various concentrations of $\mathrm{C}_{2}$-ceramide for $4 \mathrm{~h}$. The extracts that were prepared from the cells were analyzed by Western blot using a mouse anti-Bcl-2 or -caspase 3 antibody. M, HindIII-digested Lamda DNA marker; V, control vector-transfected cells; C, HCV core-expressing cells.

$100 \mu \mathrm{M}$ ) for $4 \mathrm{~h}$ resulted in a gradual decrease in the level of precursor pro-caspase-3 in a dose-dependent manner. However, the pro-caspase-3 level was not significantly reduced in the 293 cells that expressed the HCV core protein. A similar inhibitory effect of the $\mathrm{HCV}$ core protein on the activation of caspase-3 was observed in the HCV coreexpressing 293 cells that were induced by $500 \mathrm{mU}$ bacterial sphingomyelinase (data not shown). Next, we determined the Bcl-2 protein level, which regulates the apoptotic cascade and protects the cells from apoptosis. In the control cells that were treated with $\mathrm{C}_{2}$-ceramide, the $\mathrm{Bcl}-2$ protein level decreased in a dose-dependent manner (Fig. 4B). However, the Bcl-2 protein level was not significantly reduced in the 293 cells that expressed the HCV core protein under the same experimental conditions. These results, therefore, suggest that the HCV core protein inhibits pro-caspase- 3 activation and sustains the Bcl-2 protein level in the cells that are treated with ceramide.

Effect of $\mathrm{C}_{2}$-ceramide on the $\mathrm{p53}$ and $\mathrm{p21}$ protein expressions in the 293 cell lines Previous studies reported that the $\mathrm{HCV}$ core protein can regulate the transcriptional machinery of diverse cellular and viral genes (Ray and Ray, 2001). For example, the HCV core protein is able to repress 
core

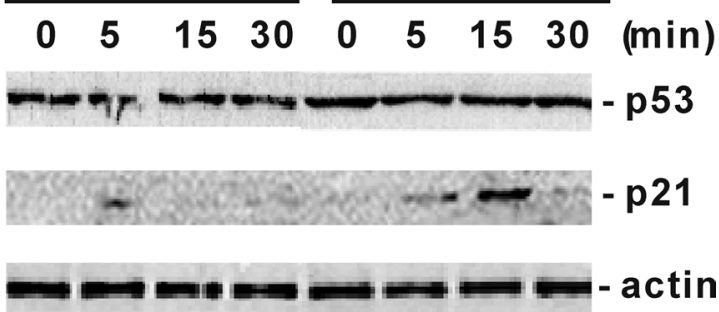

Fig. 5. Effect of $\mathrm{C}_{2}$-ceramide on the $\mathrm{p} 53$ and $\mathrm{p} 21$ protein expressions in the stably-transfected 293 cells. The 293 cells were incubated for the indicated times in the presence of 100 $\mu \mathrm{M} \mathrm{C}_{2}$-ceramide. The extracts that were prepared from the cells were analyzed by Western blot using either mouse anti-p53, antip21, or anti-actin antibodies.

the p21 and p53 promoter activities (Ray et al., 1997; Ray et al., 1998). Since p53 and p21 participate in apoptosis, we examined the effect of the HCV core protein on the p53 and p21 expressions during apoptosis that is induced by ceramide in the 293 cells. A Western blot analysis showed that treatment of the 293 cells with $\mathrm{C}_{2}$-ceramide did not change the p53 protein level in the 293 cells that expressed the HCV core protein, regardless of the HCV core protein expression (Fig. 5). However, treatment of the 293 cells that expressed the $\mathrm{HCV}$ core protein with $\mathrm{C}_{2}$-ceramide reduced the $\mathrm{p} 21$ protein expression, while the level of p21 expression in the control cells evidently increased under the same conditions (Fig. 5). These results suggest that the inhibitory effect of the HCV core protein on ceramide-induced apoptosis is partially mediated by the suppression of the p21 expression in a p53independent manner.

\section{Discussion}

Although the Hepatitis $\mathrm{C}$ virus (HCV) is worldwide the major cause of non-A, non-B hepatitis, which often leads to liver cirrhosis and hepatocellular carcinoma, the molecular mechanism of $\mathrm{HCV}$ pathogenesis still remains largely unknown (Saito et al., 1990; Di-Bisceglie et al., 1994; Shimotohno, 1995). The HCV core protein, which is involved in the $\mathrm{HCV}$ infection and pathogenesis, regulates various cellular processes, including apoptosis and cell growth (Ray and Ray, 2001). Since apoptosis is one of the key elements in the host defense against viral infections, it is believed that the inhibition of apoptosis in virus-infected cells may be a major mechanism of viral persistence, which is further required for malignant transformation. Upon virus infection, the cells produce inflammatory cytokines, such as interleukin- $1 \alpha$ and TNF- $\alpha$, as a defense mechanism to eliminate virus-infected cells. Inflammatory cytokines (such as interleukin- $1 \alpha$ and TNF- $\alpha$, environmental stresses including UV, heat shock, and oxidative stress) are known to induce ceramide generation which results in apoptotic cell death (Hannun, 1996). However, the HCV core protein may protect the virus-infected cell by suppressing ceramide-induced cell death in the HCV core-expressing cells. In this way, the HCV core protein may facilitate viral persistence during $\mathrm{HCV}$ infection. The molecular mechanisms and cascade that lead to apoptosis vary, depending on the cause of apoptosis. Therefore, we analyzed the ability of the HCV core protein to modulate ceramide-induced apoptosis. In this experiment, the production of intracellular ceramide was achieved by metabolic manipulation of ceramide levels, such as the addition of bacterial sphingomyelinase or $\mathrm{C}_{2}$-ceramide, which is a cell-permeable ceramide analog. $\mathrm{C}_{2}$-ceramide- and sphingomyelinase-mediated cell death was significantly reduced in the 293 cells that expressed the HCV core protein when compared to the control cells (Figs. 2 and 3). The protective effect of the $\mathrm{HCV}$ core protein on ceramideinduced cell death was confirmed by measuring DNA fragmentation, which served as a marker for apoptotic cell death (Fig. 4).

Although previous studies reported that the HCV core exerted a suppression of apoptosis, induced by various stimuli including cisplatin or the inappropriate overexpression of cmyc (Ray et al., 1996), the exact mechanism was not elucidated. We investigated the effect of the HCV core protein on the activation of the caspase- 3 and $\mathrm{Bcl}-2$ expressions that are induced by ceramide in the stably-transfected 293 cells. The inhibitory effects of the $\mathrm{HCV}$ core protein on the activation of caspase- 3 induced by $\mathrm{C}_{2}$-ceramide (Fig. 4B) or bacterial sphingomyelinase (data not shown) were observed in the HCV core-expressing 293 cells when compared to the control cells. In addition, the Bcl-2 protein level was not significantly reduced in the 293 cells that expressed the HCV core protein under the same experimental conditions. The Bcl2 protein regulates the apoptotic cascade and protects cells from apoptosis. Therefore, the sustained level of the Bcl-2 protein may be the possible mechanism by which the $\mathrm{HCV}$ core protein suppresses ceramide-induced apoptosis.

The tumor suppressor proteins, p53 and p21 ${ }^{\text {Wafl }}$, which is one of p53 downstream mediators, were then analyzed in the stably-transfected 293 cells. The p53 expression level was unchanged by treatment at increasing concentrations of ceramide in the 293 cells that either expressed or did not express the HCV core protein (Fig. 5). A previous study reported that the $\mathrm{HCV}$ core protein can repress $\mathrm{p} 53$ promoter activity (Ray et al., 1997). This result is inconsistent with ours; in the HCV core-expressing cell lines, the p53 levels were unaffected by the expression of the HCV core protein. The reason for this discrepancy is currently unknown. On the other hand, the p21 expression level in the control cells was evidently increased by the ceramide treatment. Although the p21 activity can be transcriptionally regulated by the p53 tumor suppressor protein, its induction can also be activated in a p53-independent manner. During ceramide-mediated apoptosis in human hepatocarcinoma cells, p21 was induced 
in a p53-independent manner (Oh et al., 1998; Kim et al, 2000). However, under the same conditions, the p21 protein expression level was barely detectable during the periods they were treated with $\mathrm{C}_{2}$-ceramide in the 293 cells that expressed the HCV core protein (Fig. 5). This result suggests that apoptosis that is induced by ceramide is mediated by the increased p21 activity in a p53-independent manner. Therefore, the inhibitory effect of the HCV core protein on ceramide-induced apoptosis appears to be partially mediated through the suppression of the p21 protein expression in a p53-independent manner. Previous studies reported that the $\mathrm{HCV}$ core protein was able to repress the p21 expression transcriptionally as well as post-transcriptionally (Ray et al., 1998; Yoshida et al., 2001).

These results indicate that the expression of the HCV core protein is able to alter the processes of apoptotic cell death that is induced by ceramide. Thus, our studies implicate that the ability of the $\mathrm{HCV}$ core protein to modulate various signaling pathways may play an important roles in determining the cell fate upon various stimuli. It is plausible that the elucidation of the protein expression profiling that is related to the apoptotic processes in the HCV-infected cells could lead to a better understanding of the mechanism by which the HCV core exerts its suppressive effect on ceramideinduced cell death. Therefore, our results demonstrate that the $\mathrm{HCV}$ core protein suppresses the ceramide-induced apoptosis by inhibiting p21 activation and sustaining the Bcl-2 level.

Acknowledgments The author (J. Park) wishes to acknowledge the financial support of the Korea Research Foundation made in the program year of 1998 (019-D00112). This work was partially supported by a research grant from the Hallym University, Korea.

\section{References}

Aach, R. D., Stevens, C. E., Hollinger, F. B., Mosley, J. W., Peterson, D. A., Taylor, P. E., Johnson, R. G., Barbosa, L. H. and Nemo, G. J. (1991) Hepatitis C virus infection in posttransfusion hepatitis. An analysis with first- and secondgeneration assays. New Engl. J. Med. 325, 1325-1329.

Bradford, M. A. (1976) A rapid and sensitive method for the quantification of microgram quantities of protein utilizing the principle of protein-dye binding. Anal. Biochem. 72, 248-254.

Chang, J., Yang, S. H., Cho, Y. G., Hwang, S. B., Hahn, Y. S. and Sung, Y. C. (1998) Hepatitis C virus core from two different genotypes has an oncogenic potential but is not sufficient for transforming primary rat embryo fibroblasts in cooperation with the H-ras oncogene. J. Virol. 72, 3060-3065.

Cho, Y. -G., Yoon, J. -W., Jang, K. -L., Kim, C. -M. and Sung, Y. -C. (1993) Full genome cloning and nucleotide sequence analysis of hepatitis C virus from sera of chronic hepatitis patients in Korea. Mol. Cells 3, 195-202.

Choo, Q. -L., Kuo, G., Weiner, A. J., Overby, L. R., Bradley, D. W. and Houghton, M. (1989) Isolation of a cDNA clone derived from a blood-borne non-A, non-B viral hepatitis genome. Science 244, 359-362.

Chung, Y. M., Park, K. J., Choi, S. Y., Hwang, S. B. and Lee, S. Y. (2001) Hepatitis C virus core protein potentiates TNF-alphainduced NF-kappaB activation through TRAF2-IKKbetadependent pathway. Biochem. Biophys. Res. Commun. 284, 1519.

Di-Bisceglie, A. M., Simpson, L. H., Lotze, M. T. and Hoofnagle, J. H. (1994) Development of hepatocellular carcinoma among patients with chronic liver disease due to hepatitis $\mathrm{C}$ viral infection. J. Clin. Gastroenterol. 19, 222-226.

Grakoui, A., Wychowski, C., Lin, C., Feinstone, S. M. and Rice, C. M. (1993) Expression and identification of hepatitis C virus polyprotein cleavage products. J. Virol. 67, 1385-1395.

Hannun, Y. A. (1996) Functions of ceramide in coordinating cellular responses to stress. Science 274, 1855-1859.

Hijikata, M., Kato, N., Ootsuyama, Y., Nakagawa, M. and Shimotohno, K. (1991) Gene mapping of the putative structural region of the hepatitis $\mathrm{C}$ virus genome by in vitro processing analysis. Proc. Natl. Acad. Sci. USA 88, 5547-5551.

Honda, M., Kaneko, S., Shimazaki, T., Matsushita, E., Kobayashi, K., Ping, L. -H., Zhang, H. -C. and Lemon, S. M. (2000) Hepatitis $\mathrm{C}$ virus core protein induces apoptosis and impairs cell-cycle regulation in stably transformed Chinese hamster ovary cells. Hepatology 31, 1351-1359.

Inchauspe, G., Zebedee, S., Lee, D. -H., Sugitani, M., Nasoff, M. and Prince, A. M. (1991) Genomic structure of the human prototype strain $\mathrm{H}$ of hepatitis $\mathrm{C}$ virus: Comparison with American and Japanese isolates. Proc. Natl. Acad. Sci. USA 88, 10292-10296.

Kato, N., Hijikata, M., Ootsuyama, Y., Nakagawa, M., Ohkoshi, S., Sugimura, T. and Shimotohno, K. (1990) Molecular cloning of the human hepatitis $\mathrm{C}$ virus genome from Japanese patients with non-A, non-B hepatitis. Proc. Natl. Acad. Sci. USA 87, 9524-9528.

Kolesnick, R. N. and Kronke, M. (1998) Regulation of ceramide production and apoptosis. Annu. Rev. Physiol. 60, 643-665.

Kim, C. -H., Park, Y. -S., Chung, K. -N. and Elwood, P. C. (2002) Sorting and function of the human foliate receptor is independent of the caveolin expression in fisher rat thyroid epithelial cells. J. Biochem. Mol. Biol. 35, 395-402.

Kim, S. Y., Kim, R. H., Huh, T. -L. and Park, J. -W. (2001) $\alpha$ Phenyl- $N$-t-butylnitrone protects oxidative damage to HepG2 cells. J. Biochem. Mol. Biol. 34, 43-46.

Kim, W. H., Kang, K. H., Kim, M. Y. and Choi K. H. (2000) Induction of p53-independent p21 during ceramide-induced G1 arrest in human hepatocarcinoma cells. Biochem. Cell. Biol. 78, 127-135.

Lee, S. W., Han, S. I., Kim, H. H. and Lee, Z. H. (2002) TAK1dependent activation of AP-1 and c-Jun N-terminal kinase by receptor activator of NF-אB. J. Biochem. Mol. Biol. 35, 371376.

Lin, C., Lindenbach, B. D., Pragai, B. M., McCourt, D. W. and Rice, C. M. (1994) Processing in the hepatitis C virus E2-NS2 region: identification of $\mathrm{p} 7$ and two distinct E2-specific products with different C termini. J. Virol. 68, 5063-5073.

Lo, S. -Y., Masiarz, F., Hwang, S. B., Lai, M. M. C. and Ou, J.H. (1995) Differential subcellular localization of hepatitis C virus core gene products. Virology 213, 455-461.

Manabe, S., Fuke, I., Tanishita, O., Kaji, C., Gomi, Y., Yoshida, S., Mori, C., Takamizawa, A., Yoshida, I. and Okayama, H. 
(1994) Production of nonstructural proteins of hepatitis C virus requires a putative viral protease encoded by NS3. Virology 198, 636-644.

Marusawa, H., Hijikata, M., Chiba, T. and Shimotohno, K. (1999) Hepatitis $\mathrm{C}$ virus core protein inhibits Fas- and tumor necrosis factor alpha-mediated apoptosis via NF-kappaB activation. $J$. Virol. 73, 4713-4720.

Matsumoto, M., Hsieh, T. -Y., Zhu, N., VanArsdale, T., Hwang, S. B., Jeng, K. -S., Gorbalenya, A. E., Lo, S. -Y., Ou, J. -H., Ware, C. F. and Lai, M. M. C. (1997) Hepatitis C virus core protein interacts with the cytoplasmic tail of lymphotoxin-beta receptor. J. Virol. 71, 1301-1309.

Oh, W. J., Kim, W. H., Kang, K. H., Kim, T. Y., Kim, M. Y. and Choi, K. H. (1998) Induction of p21 during ceramide-mediated apoptosis in human hepatocarcinoma cells. Cancer Lett. 129, 215-222.

Park, K. J., Choi, S. H., Koh, M. S. Kim, S. W. and Hwang, S. B. (2000) Identification of a cellular protein interacting with RNA polymerase of hepatitis C virus. J. Biochem. Mol. Biol. 30, 5962.

Park, K. J., Choi, S. H., Koh, M. S., Kim, D. J., Yie, S. W., Lee, S. Y. and Hwang, S. B. (2001) Hepatitis C virus core protein potentiates c-Jun N-terminal kinase activation through a signaling complex involving TRADD and TRAF2. Virus Res. 74, 89-98.

Ray, R. B., Lagging, L. M., Meyer, K. and Ray, R. (1996) Hepatitis C virus core protein cooperates with ras and transforms primary rat embryo fibroblasts to tumorigenic phenotype. J. Virol .70, 4438-4443.

Ray, R. B., Lagging, L. M., Meyer, K., Steele, R. and Ray, R. (1995) Transcriptional regulation of cellular and viral promoters by the hepatitis C virus core protein. Virus Res. 37, 209-220.

Ray, R. B., Meyer, K. and Ray, R. (1996) Suppression of apoptotic cell death by hepatitis $\mathrm{C}$ virus core protein. Virology
226, 176-182.

Ray, R. B., Meyer, K., Steele, R., Shrivastava, A., Aggarwal, B. B. and Ray, R. (1998) Inhibition of tumor necrosis factor (TNFalpha)-mediated apoptosis by hepatitis $\mathrm{C}$ virus core protein. $J$. Biol. Chem. 273, 2256-2259.

Ray, R. B., Steele, R., Meyer, K. and Ray, R. (1997) Transcriptional repression of $\mathrm{p} 53$ promoter by hepatitis $\mathrm{C}$ virus core protein. J. Biol. Chem. 272, 10983-10986.

Ray, R. B., Steele, R., Meyer, K. and Ray, R. (1998) Hepatitis C virus core protein represses $\mathrm{p} 21^{\mathrm{WAF} / / \mathrm{C} i / / \text { Sid } 1}$ promoter activity. Gene 208, 331-336.

Ray, R. B. and Ray, R. (2001) Hepatitis C virus core protein: intriguing properties and functional relevance. FEMS Microbiol. Lett. 202, 149-156.

Saito, I., Miyamura, T., Ohbayashi, A., Harada, H., Katayama, T., Kikuchi, S., Watanabe, Y., Koi, S., Orji, M., Ohta, Y., Choo, Q. -L., Houghton, M. and Kuo, G. (1990) Hepatitis C virus infection is associated with the development of hepatocellular carcinoma. Proc. Natl. Acad. Sci. USA 87, 6547-6549.

Shim, M. J., Kim, H. J., Yang, S. J., Lee, I. S., Choi, H. I. and Kim, T. U. (2002) Arsenic trioxide induces apoptosis in chronic myelogenous leukemia K562 cells: possible involvement of p38 MAP kinase. J. Biochem. Mol. Biol. 35, 377-383.

Shimotohno, K. (1995) Hepatitis C virus as a causative agent of hepatocellular carcinoma. Intervirology 38, 162-169.

Teodoro, J. G. and Branton, P. E. (1997) Regulation of apoptosis by viral gene products. J. Virol. 71, 1739-1746.

Zhu, N., Khoshnan, A., Schneider, R., Matsumoto, M., Dennert, G., Ware, C. and Lai, M. M. C. (1998) Hepatitis C virus core protein binds to the cytoplasmic domain of tumor necrosis factor (TNF) receptor 1 and enhances TNF-induced apoptosis. J. Virol. 72, 3691-3697. 